\title{
Blind eye for financial perils
}

\section{London}

SIR Peter Swinnerton-Dyer, chief executive of the UK Universities Funding Council (UFC), last week surprised a House of Commons committee when he admitted that he had no means of knowing whether a financial crisis similar to that which almost forced the closure of University College, Cardiff in 1987 was building up at another British university.

Giving evidence to the Public Accounts Committee, Swinnerton-Dyer said the UFC has to rely on the accuracy of financial forecasts provided by individual universities. The UFC "is not staffed or funded", he said, to check these figures independently. Accurate financial forecasting by universities beyond 1991 had also become more difficult since the UFC introduced its competitive bidding system for undergraduate places, SwinnertonDyer said.

\section{JAPANESE SCIENCE \\ Polite bows to the West}

\section{Tokyo}

JAPANESE scientists have a low opinion of the quality of Japanese research institutes and universities according to a survey released by the Science and Technology Agency (STA) last week.

Only a handful of the scientists surveyed were prepared to say that Japan has any centres of academic excellence; instead, nearly all chose institutes in the United States and Europe when asked to name such centres.

The respondents were 385 members of the Science Council of Japan, an elected body of distinguished academics. They were asked to name up to three centres of excellence overseas and one or more in Japan if they thought any existed. Only 11 scientists, less than three per cent, named any Japanese institutes at all.

The National Institutes of Health in the United States received the most votes (38), followed by Massachussetts Institute of Technology (29) and Max-PlankGesellschaft (28) in West Germany.

The National Laboratory of High Energy Physics in Tsukuba was one of the few Japanese institutes to win some votes (9).

But are these scientists doing their own country justice or are they just being modest? Japan's Institute of Space and Astronautical Science (ISAS), which last month launched a spacecraft to the Moon, is widely recognized outside Japan as a world leader in X-ray astronomy and other areas of astrophysics.

It is also one of the most international institutes in Japan with a large complement of foreign scientists. But this institute received only two votes. David Swinbanks
Universities will not know until next year how many students they will be teaching in each subject from 1991-92.

UFC's written evidence to the committee shows that 44 out of 74 universities (including colleges within the University of London) predict a deficit by the end of the present academic year.

Swinnerton-Dyer identified "a lack of realism" amongst the management of some universities as a contributing factor, but refused to comment in a public meeting on the financial position of particular institutions. Doing so might alarm universities' creditors, he argued.

Committee members were critical of UFC's negotiations with the University of London, whose finances are causing the UFC "serious anxiety". SwinnertonDyer said he had ensured that London's funds were properly managed so far as the autonomy of London's colleges allowed. Terry Davis, a Labour Member of Parliament, accused SwinnertonDyer of "sheltering behind academic freedom".

The committee was concerned that in reducing deficits, institutions might have to make such large cut-backs that they no longer merited the title of 'university'. Swinnerton-Dyer said that this had not yet been the case, but "enough cuts would make this problematical".

The Committee of Vice-Chancellors and Principals (CVCP) is also worried about the maintenance of standards in the face of accumulating financial deficits. In a statement delivered to the Public Accounts Committee to coincide with its inquiry, the CVCP warns that "unless more money is provided . . ., the present and planned expansion of student numbers in universities will mean a decline in the quality of education provided".

Swinnerton-Dyer also revealed that the UFC may soon face court action from the University of Edinburgh. The UFC is withholding payment of about $£ 200,000$ to cover pension payments to Edinburgh academics who took early retirement under the old University Grants Committee's (UGC) restructuring programmes, on the grounds that these staff have been re-engaged on a part-time basis. But $\mathrm{Sir}$ David Smith, principal of Edinburgh, says that the UFC has changed the rules. In any case, Edinburgh argues, the staff concerned are not being paid from the UFC's block grant.

Swinnerton-Dyer said that the UGC never intended that staff could be reengaged in this way, except to fulfil existing course requirements, but conceded that UGC circular letters explaining the early retirement programmes may have been ambiguous.
Gamma-ray detector to be built

\section{London}

ThE British Science and Engineering Research Council (SERC) and the French Centre National de la Recherche Scientifique (CNRS) last week signed a $£ 5$ million agreement to build EUROGAM, the world's most sensitive gamma-ray detector array.

The equipment will investigate the structure of atomic nuclei, produced by ion collisions. EUROGAM will be built at SERC's Daresbury laboratory, in Cheshire, coming on line in late 1991. A year later, the entire array will move to the CNRS accelerator in Strasbourg.

Professor E. W. J. (Bill) Mitchell, SERC chairman, describes the sharing of equipment between sites in different European countries as "an interesting and new way of working". Although the arrangement is chiefly a diplomatic measure, necessary to attract joint support, there may be some scientific benefits: Daresbury and Strasbourg have complementary instrumentation. Researchers at Daresbury initially sought full funding from SERC, but were asked to find a collaborator. Peter Aldhous

\section{US patent awards \\ Washington}

NEARLY half of all US patents are now awarded to foreigners, according to figures in the new issue of the US National Science Board's biennual report, Science and Engineering Indicators - 1989. That percentage fits quite well with figures showing that the United States does almost half of the Western world's total

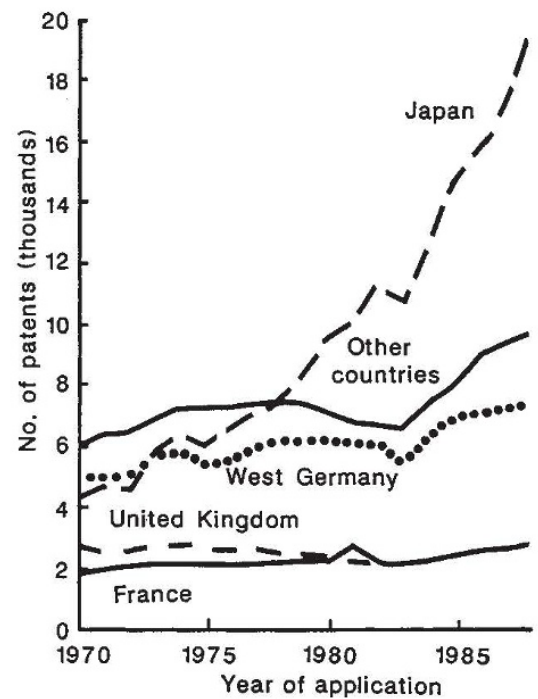

research and development. Japan's burgeoning patent inventory also fits with its rapidly increasing support for research and development. Between 1974 and 1984, the number of patents Japan gained in the United States increased around fourfold; its expenditure on research and development increased threefold. The UK share of US patents remained almost unchanged over the same period, as did its research and development expenditure in constant dollars. 